\title{
China's Departure from Its Long-Standing Non-Interference Foreign Policy in the Middle East
}

\section{Jovita Putri}

Mahasiswa Jurusan Hubungan Internasional, Fakultas IImu Sosial dan Ilmu Politik, Universitas Katolik Parahyangan

\begin{abstract}
Abstrak
Sebagai kekuatan ekonomi terbesar kedua setelah Amerika Serikat, Tiongkok telah menunjukkan kehebatannya serta peran aktifnya dalam lingkup global. Pandangan elit Beijing yang selama ini didominasi oleh kebijakan luar negeri yang bersifat non-intervensi, kini telah mengambil jalur yang berbeda. Sebagai negara industri maju, Tiongkok menaruh perhatian lebih pada sektor industri. Maka dari itu, energi merupakan salah satu kepentingan vital yang harus dicapai dan dijaga Tiongkok. Salah satu negara mitra pengekspor minyak ke Tiongkok adalah negara-negara di kawasan Timur Tengah. Berbagai kisruh politik dan konflik internal maupun internasional yang terjadi di kawasan tersebut seakan menjadi peringatan bagi Tiongkok untuk turut andil demi menjaga kepentingan nasionalnya. Relevansi prinsip kebijakan luar negeri non-intervensi Tiongkok ditantang oleh berbagai tuntutan dan tekanan internasional. Oleh karena itu, paper ini bertujuan untuk meninjau relevansi prinsip kebijakan luar negeri non-intervensi Tiongkok terhadap kawasan di Timur Tengah.

Kata Kunci: China, Middle East, China's Foreign Policy Principle, Energy, One Belt One Road, Trump's administration.
\end{abstract}

\section{Is China Really Leaving Behind Its Long-Standing Non-Interference Foreign Policy in the Middle East?}

China's staunch neutrality in the Middle East has been its main foreign policy principle towards the Arab countries. Dated back to the era of China's civilization 5,000 years ago, the era of Confucianism, and the era where external invasion and imperial domination prevails. ${ }^{1}$ The presence and domination of external forces in its mainland helped to forge its foreign policy principles, namely mutual respect of

\footnotetext{
${ }^{1}$ Dure Shahwar Bano and Mominyar Khalid, "FROM ISOLATION TO PARTICIPATION: ROLE OF CHINA IN THE UNITED NATIONS IN THE POST-COLD WAR ERA," The Journal of Political Science 33, (2015): 46, https://search.proquest.com/docview/1842431570?accountid=31495.
} 
territorial integrity; non-aggression; non-interference in the internal issues of a state; equality; and peaceful co-existence. ${ }^{2}$ China's excruciating past compelled the Chinese to adopt an isolationist foreign policy, favorable for its own nationalism and made the Chinese did not like to join the world for quite some time. ${ }^{3}$ The peaceful co-existence principle has been the cornerstone of China's foreign relations and its dealings with other countries. This principle also brought respect for state sovereignty as well as territorial integrity, due to China's long history of external intervention and land occupation.

The peaceful co-existence principle has also forged the China's staunch neutrality in the Middle East, which has prevailed long before 2017. But recent moves made by the Chinese government on their foreign relations with the Arab countries has raised some eyebrows. China's foreign policy towards the Middle East can be seen by several foreign policy decisions in the era of President Xi Jinping and Premier of the State Council, Li Keqiang, further indicating the new grand strategy for the Middle East. The highlight of China's new grand strategy for the Middle East is that it's moving closer towards the region. ${ }^{4}$ One of them can be seen by several visits by President Xi Jinping to the Middle East, included Egypt, Saudi Arabia, and the United Arab Emirates, all the majority Sunni countries. ${ }^{5}$ During his Middle East trip, the president also stopped in Tehran to sign 17 economic and technological agreements, becoming the first foreign leader to visit Iran since the sanctions against it been lifted. ${ }^{6}$

China even got itself involved into the Syrian crisis, by inviting both Syrian Foreign Minister Walid al-Moallem and the head of the opposition group, the Syrian

\footnotetext{
${ }^{2}$ Ibid.

${ }^{3}$ Ibid, 47.

${ }^{4}$ Gal Luft, "China's New Grand Strategy for the Middle East," Foreign Policy, last updated on January 26, 2016, http://www.foreignpolicy.com/2016/01/26/chinas-new-middle-eastgrand-strategy-iran-saudi-arabia-oil-xi-jinping/.

${ }^{5}$ Ibid.

${ }^{6}$ Cindy, "China's New Grand Strategy for the Middle East," China Digital Times, last updated on January 27, 2016, http://chinadigitaltimes.net/2016/01/chinas-new-grandstrategy-for-the-middle-east/.
} 
National Coalition (SNC), to high-level meeings in Beijing as an effort to promote peaceful resolutios. ${ }^{7}$ If inviting the parties involved in the Syrian crisis is not enough, China was sending Xie Xiaoyan, a career diplomat and a former ambassador to Iran, as a special envoy for the Syrian crisis in order to push peace talks and peaceful resolution. ${ }^{8}$ Aside from efforts made by the Chinese to generate peace talk and resolution in the Middle East growing conflicts, China also has its own problems with the Muslim-majority territory in northwest China, Xinjiang. In a recent event in 2016, China received criticism due to its 'repressive' treatment of the Uyghur Muslims in Xinjiang. ${ }^{9}$ In order to promote a more positive image of China to the Arab countries, China's leaders are pouring a large amount of approximately $\$ 3.5$ billion to transform Yinchuan - a home to the Hui Muslim (Chinese-speaking Muslims and ethnically Chinese) - into a "World Muslim City" and build a mosque resembling "Golden Palace" in the Arabic literature. ${ }^{10}$ This investment was done due to diplomatic strategy of creating closer ties with the Middle East by emphasizing common ground in history and culture, shared by the Sino-Arab. ${ }^{11}$ President Xi Jinping further published a white paper contemplating his plans to gain more influence in the Middle East.

The question is clear, whether or not China is leaving behind its long-standing non-interference foreign policy in the Middle East. But, the answer is still vague. So is the Arab policy paper made by China. Thus, this paper is trying to answer the questions put forward by examining the factors that might indicate China's departure from its long-standing foreign policy in the Middle East. The first part of the paper is

\footnotetext{
${ }^{7}$ Luft, "China's New Grand Strategy."

${ }^{8}$ Niu Song, "Neutrality gives China edge in the Middle East," Global Times, last updated on April 11, 2016, http://www.globaltimes.cn/content/978083.shtml.

${ }^{9}$ Elizabeth Winkler, "China is building a Muslim Theme Park to promote its statesanctioned version of Islam," Quartz, last updated on May 13, 2016, https://qz.com/683589/china-is-building-a-muslim-theme-park-to-promote-its-statesanctioned-version-of-islam/.

${ }^{10}$ Ibid.

${ }^{11}$ Ibid.
} 
presenting the facts of China's departure in its non-interference foreign policy in the Middle East; the second part of the paper is presenting the neorealist perspectives as the main notion in the analysis; the third part of the paper is going to examine the factors influencing the China's shift in foreign policy towards the Middle East, presented by three driving forces, mainly the energy, the ISIS factor, and the U.S. vacuum in the Middle East; while the last part of the paper will wrap up the whole discussion.

\section{How the Classical Realist views China's New Grand Strategy for the Middle East}

One of the Classical Realist thinker, Niccolo Machiavelli, emphasized the values of security and survival of the state as main forces in guiding the state's foreign policy. The leaders of a country must take its responsibility in protecting their country and its citizens. In doing so, Machiavelli envision that a leader must be as strong as the lion, and deceptive as the fox. Power and deception are two essential means for the conduct of foreign policy. The main responsibility of rulers is to seek advantages and to defend state's interests as well as to ensure its survival. Classical realist perceives the world as an anarchical and dangerous world, but also an opportune one. To survive, rulers must always be aware of any dangers and take any necessary precautions against them. And to prosper, rulers must recognize and exploit the opportunities presented to them. Those survival and prosperity rules are suggesting that the conduct of foreign policy is an instrumental activity of a country. In addition to that, Machiavelli stressed that rulers have to be both powerful and deceptive in the conduct of their foreign policy, since their people depend upon them for their survival and prosperity. ${ }^{12}$

\footnotetext{
${ }^{12}$ Robert Jackson and Georg Sorensen, Introduction to International Relations: Theories and Approaches, fifth edition (Oxford: Oxford University Press, 2013), 69-70.
} 
China's shift in its foreign policy in the Middle East is acceptable according to the Classical Realist, since this world is a dangerous and opportune place. Just like the Middle East, a tumultuous region, but also full of opportunities. China, being an emerging global player has the responsibility to show its active role in the global sphere. In doing so, it's not merely for the sake of its global image, but also to maintain its national interest, since closer ties with the region means a more active role in helping to resolve foreign affairs in the conflicting region. The Middle East, a dangerous place that could threaten many of China's growing national interests in the region, not only national interest, but also its national security. Despite its conflicting nature, the Middle East is also an opportune place for the Chinese to show its role as the global power in the region as well as in achieving China's interest, mainly the "One Belt, One Road” (OBOR) policy, and if it succeed in grabbing the opportunities, the Classical Realist thinks that the opportunity could bring great advantages to China. The next parts will elaborate the factors China's facing that might change its staunch of neutrality in the Middle East.

\section{China's Thirst for Energy and the 'One Belt, One Road' Initiative}

In history, China has been known as a great player in the economic sphere and the king of the industry. Industry itself has been one of the driving forces to the economy of China. ${ }^{13}$ Industry means energy. And to fuel up its economy, China needs a lot of it. In order to satisfy its thirst for energy, China travels all the way to the Arab countries, the hydrocarbon-rich lands. China's energy import from the Middle East constitutes mostly by crude oil. To satisfy the ever-increasing demand for industrial needs at home, China has quickly surpassed the U.S. as the world's largest oil importer, where 50 percent of its oil imports come from the Middle East. ${ }^{14}$ The crude

\footnotetext{
${ }^{13}$ Zuliu Hu and Mohsin S. Khan, "Why Is China Growing So Fast?” Economic Issues, no. 8, (1997): 9, https://www.imf.org/EXTERNAL/PUBS/FT/ISSUES8/issue8.pdf.

${ }^{14}$ Keith Johnson, "China Tops U.S. As Biggest Oil Importer," Foreign Policy, last updated on May 11, 2015, http://foreignpolicy.com/2015/05/11/china-tops-u-s-as-biggest-oilimporter-middle-east-opec-sloc/.
}

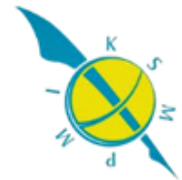


oil comes mainly from Saudi Arabia, accounted for $16 \%$ of China's net oil import, about one million barrel per day, followed by Oman (10\%), Iraq (9\%), Iran (9\%), United Arab Emirates (4\%), and Kuwait (3\%), leaving behind another forty nine percent to other regions. ${ }^{15}$

Despite its oil-rich land, the Middle East has also been one of the most tumultuous regions in the world. And the term 'conflict' seems like an interchangeable term for the region. Long history has never made peace with the region, and the region may shortly be described as a region that's busy with smokes and guns. While China, the second largest economy in the world, is always busy with its economic and industrial plan, in search of energy. Once a net oil exporter, China is now a net oil importer, raising new concern for the energy security planners in China. ${ }^{16}$ Growing reliance of China's oil needs to the region has left loopholes in China's energy security. Having a history of using oil as a foreign policy tool has made China to be aware that growing dependence on foreign oil can badly influence one's national interest. ${ }^{17}$ In order to accommodate its reliance on foreign oil to sustain its economy, China invested much of its money abroad for energy projects to more than 50 countries. ${ }^{18}$ Due to its supersize economy, one of the main forces in determining China's foreign policy is its economy. In order to sustain the economy owing to massive industrial growth and production, China needs to secure its energy needs. The needs were manifested into the OBOR policy initiated by President Xi Jinping in 2013.

\footnotetext{
${ }^{15}$ Statista, "Breakdown of China's crude oil imports in 2014, by source country," last updated on 2014, https://www.statista.com/statistics/221765/chenese-oil-imports-bycountry/.

${ }^{16}$ Erica Strecker Downs, China's Quest for Energy Security (Santa Monica, CA: RAND Corportation, 2000), 12.

${ }^{17}$ Ibid, 44.

${ }^{18}$ Tyler Durden, "Where Does China Import Its Energy from (And What This Means for the Petroyuan)," ZeroHedge, last updated on January 20, 2014, http://www.zerohedge.com/news/2014-01-20/where-does-china-import-its-energy-andwhat-means-petroyuan.
}

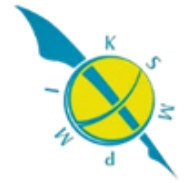


Since President Xi Jinping's rise to power, he has been making the Chinese foreign policy stance on various issues clear and expressed his desire of revitalizing the nation, called the "China Dream". ${ }^{19}$ The "China Dream" has since become the important starting point in creating the OBOR policy, focusing on securing China's trade and energy routes. ${ }^{20}$ The OBOR policy serves as a foreign policy and economic strategy for China and is created to link the Europe to China as well as the Africa and Oceania economically through countries across Eurasia and the Indian Ocean. ${ }^{21}$ The initiative encompasses five key areas of cooperation, namely coordinating development policies; forging infrastructure and facilities networks; strengthening investment and trade relations; enhancing financial cooperation; and deepening social and cultural exchanges. ${ }^{22}$ Highly ambitious OBOR wishes to link and connect 'all roads to Beijing' and in order to secure its energy routes along the way from the Middle East, OBOR serves as its ground point to sustain China's economy.

In order to carry forward the OBOR initiative, it is hardly possible to stick with its long-standing non-interference foreign policy principle in the tumultuous region. Energy is one of the most important things that drive the Chinese economy. Its growing dependence on foreign oil could be a dangerous thing, knowing that the oil mainly comes from the most riotous region in the world. Thus, securing its energy routes is crucial prerequisite to make ends meet for the Chinese. And the interest has been manifested into the OBOR initiative. There is a lot to do in implementing the OBOR initiative, one of them leaving no spot for China's foreign policy principle of non-interference. Moderating its non-interference stance and taking more proactive

${ }^{19}$ Umbreen Javaid and Meer Waheed, "China's Foreign Policy in the Middle East," South $\begin{array}{llllll}\text { Asian } & \text { Studies 31, no. } & 2 & \text { (Jul, } & \text { 2016): } & 324 \text {, }\end{array}$ https://search.proquest.com/docview/1864148277? accountid=31495.

${ }^{20}$ Ibid.

${ }^{21}$ Geoff Wade, “China's 'One Belt, One Road' Initiative,” Parliament of Australia, accessed on April 10, 2017,

http://www.aph.gov.au/About_Parliament/Parliamentary_Departments/Parliamentary_Librar y/pubs/BriefingBook45p/ChinasRoad.

${ }^{22}$ Ibid.

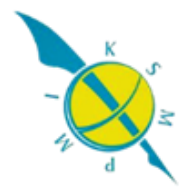


stance in the region's affairs are important in implementing the OBOR as well as maintaining its economic and political interest in the region. ${ }^{23}$

\section{The ISIS Factor}

Syrian crisis, involving not only global powers but also non-state actors, mainly the ISIS. An armed terrorist group that's not only causing menace in the region, but throughout other part of the world as well. China is no exception. Xinjiang is the region in China in which majority of Uyghur (Turkic speaking) Muslims live in China. Apparently, threats from the ISIS are getting closer to Beijing through the Uyghur community in Xinjiang. China is concerned with the increasing number of militants of Chinese Uyghurs who have joined the ISIS and bringing the serious threats home, risking its national security. ${ }^{24}$ Playing more active role in the crisis would prevent the spillover to reach China. And if China doesn't take any role in the crisis, it cannot prove itself as a responsible global player. Injecting itself into the conflict may prove its power to the Arab countries by reflecting China's positive international and regional image as well as achieving its political and economic interest. ${ }^{25}$

The ISIS also imposes threats to China's economic interest (energy) and further the implementation of the OBOR. In ensuring the success of the OBOR, it is essential to maintain a stable and peaceful region, since the region lies within the OBOR's strategic planned routes. China's envoy for the Syrian crisis, Xie Xiaoyan, stated that "China is ready to work with other major powers, including Russia, in post-war reconstruction efforts in Syria." ${ }^{26}$ Thus, eliminating the ISIS factor, is not only

\footnotetext{
${ }^{23}$ Mordechai Chaziza, "SYRIA'S CIVIL WAR: STAGE FOR GREATER CHINESE INVOLVEMENT IN THE MIDDLE EAST?" Middle East Review of International Affairs (Online) 20, no. 2 (Summer, 2016): 3, https://search.proquest.com/docview/1835983416?accountid=31495.

${ }^{24}$ Chaziza, "Syria’s Civil War," 2-3.

${ }^{25}$ Ibid.

${ }^{26}$ Romanjuk, "China's 'Arab Pivot'.”
} 
important for the energy and the OBOR, but also to maintain China's own national security. And in doing so, China is offering military training and humanitarian supplies in Syria, as well as having a new anti-terrorism law, giving China more space to conduct counterterrorism mission overseas. ${ }^{27}$ In 2016 , China's military officials coordinated a cooperation and military assistance, together with Russia and Syria's military officials. ${ }^{28}$ This cooperation is indicating China's increased awareness for more military presence in the region.

\section{U.S. Absence in the Middle East}

Another external factor that drives the Chinese to call it quit on its staunch neutrality in the Middle East, is the rarely-seen U.S. absence in the Middle East. This event is mainly a 'bonus' and opportunity for the Chinese. During the second Obama administration, the world has seen the decreasing involvement of the U.S. in the Middle East, mainly prior to its two unsuccessful wars in the region, signaling its limited power in the region, and also due to its decreasing dependency on energy from the Middle East, thanks to its fracking technology. ${ }^{29}$ Under Obama, the U.S. has made limited and unsuccessful effort in its campaign against ISIS. After the Obama administration, the Trump administration resumes the power in 2017. One of the first moves that Trump made is the cuts in foreign military spending, mainly the foreign aid. ${ }^{30}$ The money will overflow in bigger amount to the Pentagon, but not for foreign use, rather for the U.S. domestic defense, such as buying warships and warplanes, increasing the number of American ground troops and modernizing the nuclear

\footnotetext{
${ }^{27}$ Ibid.

${ }^{28}$ Ibid.

${ }^{29}$ Efraim Inbar, "Consequences of American Retreat from the Middle East," Middle East Issues: AS U.S. Regional Influence Wanes, Russia, Iran, \& China Exploit the Vacuum, Vol. XI, no. 3.748, (2016): 1, http://www.isranet.org/middle-east-issues-us-regional-influencewanes-russia-iran-china-exploit-vacuum.

${ }^{30}$ Helene Cooper and Peter Baker, "Critics Assail Cuts in Foreign Spending as Trump Moves to Boost Military Spending," The New York Times, last updated on February 27, 2017, https://www.nytimes.com/2017/02/27/us/politics/trump-foreign-military-spendingcuts-criticism.html?_r=0.
} 
arsenal. ${ }^{31}$ Limited U.S. presence in the Syrian crisis couldn't bring the conflict to an end. The Beijing policy makers are beginning to fear the possibility of spill-over in the Syrian crisis and destabilize the whole region, giving negative impacts to China's trade in the region, especially crude oil, recalling half of its oil imports come from the region. ${ }^{32}$

The lessening U.S. presence in the region means vacuum of global dominant power in the region, and also means more place for the Chinese. It's not just a mere idle talk, since China has long been making moves towards the Middle East. One quick instance is when the 9/11 stroke the U.S. hard and creating a negative sentiment of its people towards the Muslim people. Soon, Islamophobia has become ubiquitous in the U.S. and discrimination of Muslims in the U.S. takes place, thus decreasing its relations with the Arab countries. China, on the other hand, being an opportunist, has quickly grabbed the opportunity the U.S. has left behind, by establishing the ChineseArab Friendship Association (CAFA) to promote bilateral relations with the Arab countries. ${ }^{33}$ One of the organizer at the China-Arab States Economic and Trade Forum stated that, "The kind of discrimination Muslims faced in the West after 9/11 will have no place in Chinese-Arab relations," ${ }^{34}$ emphasizing China's growing interest in the Arab countries. The 2001 event is the reminder that the Chinese has not only been watching and learning a lot from the U.S., but also managed to grab many of the U.S.' lost business opportunities. When Islamophobia prevails in the West, especially the U.S., China is busy building closer ties with the Arab countries, building more mosque in China, constructing Muslim theme park, and making several trips to the Arab countries, bringing back dozens of favorable deals home. The Chinese is also filling the vacuum left by the U.S. in several conflict resolution and

\footnotetext{
${ }^{31}$ Ibid.

${ }^{32}$ Chaziza, "Syria’s Civil War," 3.

${ }^{33}$ Massoud Hayoun, "China's Approach to the Middle East Looks Familiar," The Diplomat, last updated on November 29, 2016, http://thediplomat.com/2016/11/chinas-approach-tothe-middle-east-looks-familiar/.

${ }^{34}$ Ibid.
} 
management in the region, such as one in the Syria. China has been making efforts in order to facilitate peace talks between conflicting parties in the Syrian crisis, due to the U.S. limited presence in its campaign against ISIS. Though the Chinese still clearly stated that it is against any intervention in Syria, its economic interest in the region may dictate its foreign policy to intervene in the Syrian crisis.

In addition to that, recent travel ban to the six Muslim-majority countries, namely Iran, Somalia, Sudan, Yemen, Syria and Libya ${ }^{35}$ is still in the process and culminating controversies. While the U.S. is busy with its still-in-the-working travel ban and busy cutting its budget on pretty much everything that has to do with foreign military operations, China is busy offering its Infrastructure-as-Energy deals and implementing its huge ambition of the OBOR policy by investing in building highways, railways, and other infrastructure required for the implementation of the OBOR. Aside from that, China's close relation with both Shiite and Sunni state in the region will come at the expense of relations with others. ${ }^{36}$ During 2014-2016 alone, China became actively involved in the region's affairs, such as willingly become the mediator for certain conflicts in the region, but that initiative came solely to ensure the energy security and the implementation of the OBOR.

\section{Conclusion}

After thorough elaboration of the factors that made the Chinese to change its staunch of neutrality in the conduct of its foreign policy in the Middle East, it is fair to conclude that China has a lot of reasons that force it to shift from its staunch of neutrality in the Middle East. Being an opportunist, China's clever to maneuver with

\footnotetext{
${ }^{35}$ Sabrina Siddiqui, Lauren Gambino, and Oliver Laughland, "Trump travel ban: new order targeting six Muslim-majority countries signed," The Guardian, last updated on March 6, 2017, https://www.theguardian.com/us-news/2017/mar/06/new-trump-travel-ban-muslimmajority-countries-refugees.

${ }^{36}$ Scott N. Romanjuk and Tobias J. Burgers, "China's 'Arab Pivot' Signals the End of NonIntervention," The Diplomat, last updated on December 20, 2016, http://thediplomat.com/2016/12/chinas-arab-pivot-signals-the-end-of-non-intervention/.
}

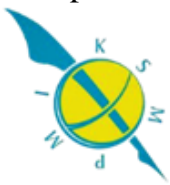


its non-interference foreign policy principle in the Middle East, but recalling that half of its oil imports come from the region, China has to rethink its staunch of neutrality in the region due to its close ties with both the Shiite and Sunni in the Arab countries. Meanwhile its close ties with the Arab countries is due to its oil demands at home. In securing the energy from the region, China is implementing a highly ambitious OBOR policy. In implementing the policy, it is hardly possible if the China to keep its staunch of neutrality in the region. If the OBOR wishes to succeed, a greater role of China in the region is expected, just like it already did in the region, taking more active role in the region, by giving humanitarian supplies and military training to the region, as well as joining the Russian allies in the conflict in 2016. Apparently, China has been busy maintaining its national security as well as prosperity as the consequences of being the new global power. Furthermore, the U.S. rare presence in the region, since the Obama administration has given the Chinese more space to get more opportunities the U.S. has left. U.S. recent sentiment on the Muslims due to its travel ban has very much benefitted the Chinese in aligning closer to the region. Recent events presented in previous parts show that China is both a strong and deceptive force in conducting its foreign policy in the region, and its long-standing non-interference foreign policy principle is facing a great challenge, due to the changing nature of China's role in the world politics, although Beijing hasn't clearly stated that it is leaving the principle behind, their actions and the OBOR foreign policy is telling other story. And in the process of implementing it, the OBOR policy hampers the relevance of China's long-standing non-interference foreign policy principle, for it to succeed, and it works the other way around.

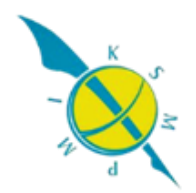




\section{BIBLIOGRAPHY}

Bano, Dure Shahwar and Mominyar Khalid. "FROM ISOLATION TO PARTICIPATION: ROLE OF CHINA IN THE UNITED NATIONS IN THE POST-COLD WAR ERA." The Journal of Political Science 33, (2015): 45-62. https://search.proquest.com/docview/1842431570?accountid=31495.

Chaziza, Mordechai. "SYRIA'S CIVIL WAR: STAGE FOR GREATER CHINESE INVOLVEMENT IN THE MIDDLE EAST?" Middle East Review of International Affairs (Online) 20, no. 2 (Summer, 2016): 1-9. https://search.proquest.com/docview/1835983416?accountid=31495.

Cindy. "China's New Grand Strategy for the Middle East." China Digital Times. Last updated on January 27, 2016. http://chinadigitaltimes.net/2016/01/chinas-new-grandstrategy-for-the-middle-east/.

Cooper, Helene and Peter Baker. "Critics Assail Cuts in Foreign Spending as Trump Moves to Boost Military Spending." The New York Times. Last updated on February 27, 2017. https://www.nytimes.com/2017/02/27/us/politics/trump-foreign-militaryspending-cuts-criticism.html?_r=0.

Downs, Erica Strecker. China's Quest for Energy Security. Santa Monica, CA: RAND Corporation, 2000. https://www.rand.org/pubs/monograph_reports/MR1244.html.

Durden, Tyler. "Where Does China Import Its Energy from (And What This Means for the Petroyuan)." ZeroHedge. Last updated on January 20, 2014. http://www.zerohedge.com/news/2014-01-20/where-does-china-import-its-energyand-what-means-petroyuan.

Hayoun, Massoud. "China's Approach to the Middle East Looks Familiar." The Diplomat. Last updated on November 29, 2016. http://thediplomat.com/2016/11/chinasapproach-to-the-middle-east-looks-familiar/.

$\mathrm{Hu}$, Zuliu and Mohsin S. Khan, "Why Is China Growing So Fast?" Economic Issues, no. 8, (1997): 1-16. https://www.imf.org/EXTERNAL/PUBS/FT/ISSUES8/issue8.pdf.

Inbar, Efraim. "Consequences of American Retreat from the Middle East." Middle East Issues: AS U.S. Regional Influence Wanes, Russia, Iran, \& China Exploit the Vacuum, Vol. XI, no. 3.748. (2016): 1-5. http://www.isranet.org/middle-east-issuesus-regional-influence-wanes-russia-iran-china-exploit-vacuum.

Jackson, Robert and Georg Sorensen. Introduction to International Relations: Theories and Approaches. Fifth edition. Oxford: Oxford University Press, 2013.

Javaid, Umbreen and Meer Waheed. "China's Foreign Policy in the Middle East." South Asian Studies 31, no. 2 (Jul, 2016): 321-331. https://search.proquest.com/docview/1864148277?accountid=31495.

Johnson, Keith. "China Tops U.S. As Biggest Oil Importer.” Foreign Policy. Last updated on May 11, 2015. http://foreignpolicy.com/2015/05/11/china-tops-u-s-as-biggest-oilimporter-middle-east-opec-sloc/.

Luft, Gal. "China's New Grand Strategy for the Middle East." Foreign Policy. Last updated on January 26, 2016. http://www.foreignpolicy.com/2016/01/26/chinas-new-middleeast-grand-strategy-iran-saudi-arabia-oil-xi-jinping/.

Romanjuk Scott N., and Tobias J. Burgers. "China's 'Arab Pivot' Signals the End of NonIntervention.” The Diplomat. Last updated on December 20, 2016.

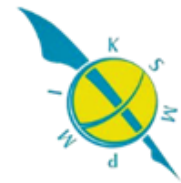


http://thediplomat.com/2016/12/chinas-arab-pivot-signals-the-end-of-nonintervention/.

Siddiqui, Sabrina, Lauren Gambino, and Oliver Laughland. "Trump travel ban: new order targeting six Muslim-majority countries signed." The Guardian. Last updated on March 6, 2017. https://www.theguardian.com/us-news/2017/mar/06/new-trumptravel-ban-muslim-majority-countries-refugees.

Song, Niu. "Neutrality gives China edge in the Middle East." Global Times. Last updated on April 11, 2016. http://www.globaltimes.cn/content/978083.shtml.

Statista. "Breakdown of China's crude oil imports in 2014, by source country." Last updated on 2014. https://www.statista.com/statistics/221765/chenese-oil-imports-by-country/.

Wade, Geoff. “China's 'One Belt, One Road' Initiative.” Parliament of Australia. Accessed on April 10, 2017.

http://www.aph.gov.au/About_Parliament/Parliamentary_Departments/Parliamentary _Library/pubs/BriefingBook45p/ChinasRoad.

Winkler, Elizabeth. "China is building a Muslim Theme Park to promote its state-sanctioned version of Islam." Quartz. Last updated on May 13, 2016.

https://qz.com/683589/china-is-building-a-muslim-theme-park-to-promote-its-statesanctioned-version-of-islam/.

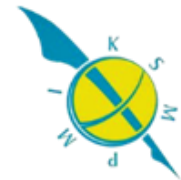

